\title{
Fitness Level Differences between Students in Kosovo and Montenegro
}

\author{
Besnik Morina ${ }^{1}$, Florian Miftari ${ }^{1, *(D)}$ and Dana Badau ${ }^{2, *(D)}$ \\ 1 Faculty of Physical Education and Sport, University of Prishtina "Hasan Prishtina", 10000 Pristina, Kosovo; \\ besnik.morina@uni-pr.edu \\ 2 "Petru Maior" Faculty of Sciences and Letters, "George Emil Palade" University of Medicine, Pharmacy, \\ Science and Technology, 540142 Târgu Mureș, Romania \\ * Correspondence: florian.miftari@uni-pr.edu (F.M.); dana.badau@umfst.ro (D.B.)
}

check for updates

Citation: Morina, B.; Miftari, F.; Badau, D. Fitness Level Differences between Students in Kosovo and Montenegro. Educ. Sci. 2021, 11, 140. https:/ / doi.org/10.3390/educsci 11030140

Academic Editor: Stephen

A. Butterfield

Received: 17 February 2021

Accepted: 19 March 2021

Published: 23 March 2021

Publisher's Note: MDPI stays neutral with regard to jurisdictional claims in published maps and institutional affiliations.

Copyright: (c) 2021 by the authors. Licensee MDPI, Basel, Switzerland. This article is an open access article distributed under the terms and conditions of the Creative Commons Attribution (CC BY) license (https:/ / creativecommons.org/licenses/by/ $4.0 /)$.

\begin{abstract}
Geographical, cultural, and socio-economic factors create a different lifestyle. Accordingly, the aim of this research was to identify the differences in anthropometric and fitness characteristics among adolescents living in Montenegro and Kosovo in order to optimize the physical fitness as a consequence of the proactive behavior. Anthropometric characteristics and fitness level measures were assessed by Eurofit testing battery among 600 Kosovar and 600 Montenegrin students, equally distributed by gender. Differences between countries, gender, and age group (13,14 and 15 years) were assessed with multivariate and univariate analysis of variance. The results showed that Montenegrin students are taller, heavier, and achieve better results in the sit-ups and 20-m endurance shuttle-run tests. Kosovar students achieve better results in the standing broad jump and $10 \times 5 \mathrm{~m}$ shuttle-run tests. Males achieve significantly better results in all tests, excluding the sit-and-reach test. Statistically significant differences among age groups were found for all variables, regardless gender and country (except for the flamingo and sit-and reach tests). This study is of importance to physical education teachers and curriculum authors to optimize students' proactive behavior based on the identified anthropometric and physical fitness differences between the two countries, age groups, and genders.
\end{abstract}

Keywords: morphology; body mass index; motor skills; Eurofit fitness tests; fitness components; students

\section{Introduction}

Geographical, cultural, and socio-economic factors create a different lifestyle. Today, however, young people living in developed countries are mainly characterized by the modern information era. Television and information technology provide easy and fast way for entertainment and communication for the young people and therefore represent important factors in their lifestyles. Many young people live in the semi-virtual world of social networks and very few of them participate in physical activities as they did in the past $[1,2]$. In connection with some other destructive trends (sheltering praxis of parents, individualization), a sedentary lifestyle is common among young people [3-6]. The results from many studies indicate that lifestyle changes in developed countries among young people increases subcutaneous fat tissue [7-9], increase the proportion of the overweight population [10-14], and decrease the fitness level, especially endurance and strength capabilities [15-18]. Most commonly, when measuring the diversity in lifestyles between countries, data are associated with differences in dietary habits, access to sports facilities, and possibilities for engaging in various physical activities, as well as in differences in education and training systems $[19,20]$.

Anthropometric measures could be an indicator of a health condition, lifestyle habits and maturity [21,22]. Thus, there is a need for studies of anthropometric features in the future. Moreover, the results from the anthropometric diagnostic could be used for the 
prediction of anthropometric features, such as development, planning, programming, and designing quality physical education curricula and programs, identification of talented children, following of body composition and fitness level, preparation of state plans, programs, and strategies for the promotion of physical activity among the population designated to achieve lifetime engagement in physical activities [23,24]. Lot of studies pointed out that the level of anthropometric features is affected by different factors, including living environment factors [25,26], lifestyle [27-29], cultural differences, socioeconomic status [30], and physical fitness.

The assessment of the fitness level in relation to the individual anthropometric parameters allows the identification of the strengths and weaknesses of the fitness level as a premise for the identification of the health level [31-33]. The components of physical fitness are approached both from the perspective of health, including five parameters (cardiovascular/aerobics fitness, strength, muscular endurance, flexibility, body composition), and physical activities, including additional six parameters (agility, balance, coordination, speed, reaction time, power) [34-36]. Both perspectives have been addressed in numerous studies, which have highlighted the importance of developing fitness since childhood in order to form proactive behaviors with a major impact on physical development, health, social integration and quality of life [36-40] among adulthood. Moreover, fitness and physical activity are important for cardiovascular and mental health, but activity and fitness levels are declining especially in adolescents and among girls [37].

Physical fitness components among adolescents can be objectively identified with anthropometric characteristics and physical abilities. Moreover, physical fitness can be optimized by adapting physical training and health education programs, with an impact on the development of proactive behaviors and a healthy lifestyle. The aim of our study was two-fold, first to assess differences in the anthropometric characteristics and the level of fitness among 13-15 years old students from the two countries (Kosovo and Montenegro), and secondly, to assess differences among gender and age, regardless the country. We hypothesized that country represents a factor that significantly influences students anthropometric and physical fitness characteristics. Moreover, we hypothesized that male and older students will achieve higher anthropometric values and better physical fitness results. Based on the identified anthropometric and physical fitness weaknesses from the results of our study, the content of physical activity education programs could be customized in order to optimize students' proactive behavior and, consequently, physical fitness.

\section{Materials and Methods}

\subsection{Participants}

The research was realized on a sample of 1200 respondents (12 groups). Of these, 600 were from Kosovo and 600 were from Montenegro. A total of six groups of males and females from each country were included (100 respondents in each group, 50 female and 50 male). They were 13,14, or 15 years old. Sample size was calculated on the basis of the $95 \%$ confidence interval and a 5\% margin of error. The ideal sample size calculated for Kosovar and Montenegrin was additionally increased by $40 \%$ to boost the statistical power of statistical tests. Convenient sampling technique was performed, selecting all of the participants that fall in inclusion criteria. The participants were treated according to Helsinki Declaration. The protocol was approved by the Ethics Committee of Faculty of Physical Education and Sport, Pristina, no. 16/02.2019. All participants were informed about the details of the study. Study participation was anonymous and voluntary. The recruitment of the participants was made on the following criteria: age, absence of illness that could in any way influence the testing results, and active participation in physical activity programs in the last 6 months. 


\subsection{Study Design}

The study was designed as an observational cross-sectional study. Anthropometric and physical fitness characteristics were assessed among the 14-, 15-, and 16-year-old pupils in March, April, and May 2019. Testing was performed in a standard school physical education setting in regular classes of health and physical education.

\subsection{Testing Procedures}

Measurements were performed by professionals from the branches of kinesiology and medicine, who were previously trained for conducting certain anthropometric or physical fitness tests, respectively. The evaluation activity was performed under the coordination of the study authors. Tests were applied at the end of a 3-month physical education (PE) cycle for each of the groups. The PE program and tests were planned at the same time for each category. All the tests were performed following Eurofit system recommendations [1] The data included two anthropometric and nine fitness tests (for details, see Table 1). In addition, body mass index (BMI) was calculated from body height and body weight. All the tests have suitable measuring characteristics, described elsewhere [41,42].

Table 1. Sample of variables.

\begin{tabular}{|c|c|c|}
\hline Test & Measured Capacity & Measuring Unit \\
\hline Body height & Longitudinal dimension of the body & $\mathrm{cm}$ \\
\hline Body mass & Volume of the body & $\mathrm{kg}$ \\
\hline Body mass index & Body mass /(Body height in meters) ${ }^{2}$ & $\mathrm{~kg} / \mathrm{m}^{2}$ \\
\hline Flamingo & to assess the ability to balance successfully on a single leg for $60 \mathrm{~s}$ & number of falls \\
\hline Plate Tapping & tests speed of limb movement & seconds \\
\hline Sit-and-Reach & flexibility test (using $15 \mathrm{~cm}$ at the level of the feet) & $\mathrm{cm}$ \\
\hline Standing Broad Jump & explosive leg power & $\mathrm{cm}$ \\
\hline Handgrip Test & $\begin{array}{c}\text { measures static arm strength, we used the best results of } 2 \text { tests for each } \\
\text { hand }\end{array}$ & $\mathrm{kg}$ \\
\hline Sit-Ups in $30 \mathrm{~s}$ & measures trunk strength & number of repetitions \\
\hline Bent Arm Hang & muscular endurance/functional strength & seconds \\
\hline $10 \times 5 \mathrm{~m}$ Shuttle-Run & measures running speed and agility & seconds \\
\hline 20 m endurance Shuttle-run & cardiorespiratory endurance & $\mathrm{km} / \mathrm{h}$ \\
\hline
\end{tabular}

\subsection{Data Analysis}

The data were analyzed using the statistical package SPSS v.22. Basic parameters of the distribution of variables were calculated (mean and standard deviation). The normality of the data distribution was confirmed with Shapiro-Wilk's test. Multivariate analysis of variance (MANOVA) was used to test the differences according to the country, age and gender. The power of the concurrent influence of the country, age and gender on the entire set of dependent variables (anthropometric measures and fitness tests) was measured by Wilks' lambda; its statistical significance was tested by Bartlett's variance test. The amount of explained variance of the entire system of dependent variables was estimated with an adjusted $R^{2}$ for the entire system of predictors (main effect-country, gender, age-and their two-way and three-way interactions) and with a partial $\eta^{2}$ for individual predictors. Univariate tests were also carried out for each dependent variable separately: F-tests for the entire model, for main effects and its interaction were applied. The selected significance threshold was set at $p \leq 0.05$

\section{Results}

Descriptive statistics of the results are presented in the Tables 1-4 and the main results of the study are presented in the Tables 5-7. Results are presented as mean \pm standard deviation. Descriptive statistics are presented for the entire sample of the study, as well as differentiated by gender, age, and the country evaluated for a clear and concise evaluation. 
Table 2. Descriptive statistics for Kosovar and Montenegrin students, differenced by gender.

\begin{tabular}{|c|c|c|c|c|c|c|}
\hline \multirow{3}{*}{ Variables } & \multicolumn{6}{|c|}{ Mean \pm Standard Deviation } \\
\hline & \multicolumn{3}{|c|}{ Kosovo } & \multicolumn{3}{|c|}{ Montenegro } \\
\hline & Male & Female & All & Male & Female & All \\
\hline Body height & $165.1 \pm 9.3$ & $160.6 \pm 6.5$ & $162.9 \pm 8.4$ & $167.1 \pm 10.3$ & $162.9 \pm 6.6$ & $165.0 \pm 8.9$ \\
\hline Body weight & $54.7 \pm 12.5$ & $51.9 \pm 10.5$ & $53.3 \pm 11.6$ & $57.7 \pm 13.8$ & $53.9 \pm 10.6$ & $55.8 \pm 12.4$ \\
\hline BMI & $19.9 \pm 3.5$ & $20.0 \pm 3.4$ & $19.9 \pm 3.4$ & $20.4 \pm 3.5$ & $20.2 \pm 3.3$ & $20.3 \pm 3.4$ \\
\hline Flamingo & $13.6 \pm 6.7$ & $13.5 \pm 5.8$ & $13.6 \pm 6.2$ & $12.4 \pm 5.4$ & $12.9 \pm 5.5$ & $12.6 \pm 5.4$ \\
\hline Plate Tapping & $10.0 \pm 1.4$ & $10.3 \pm 1.3$ & $10.2 \pm 1.3$ & $10.6 \pm 2.1$ & $10.4 \pm 1.5$ & $10.5 \pm 1.8$ \\
\hline Sit-and-Reach & $24.7 \pm 7.6$ & $30.6 \pm 8.1$ & $27.6 \pm 8.4$ & $25.5 \pm 7.7$ & $29.6 \pm 7.1$ & $27.5 \pm 7.7$ \\
\hline Standing Broad Jump & $167.8 \pm 29.1$ & $137.9 \pm 20.5$ & $152.8 \pm 29.2$ & $157.4 \pm 27.1$ & $136.7 \pm 22.2$ & $147.0 \pm 26.8$ \\
\hline Handgrip Test (right hand) & $31.2 \pm 8.9$ & $26.4 \pm 5.3$ & $28.8 \pm 7.7$ & $31.2 \pm 8.5$ & $25.7 \pm 5.5$ & $28.5 \pm 7.6$ \\
\hline Handgrip Test (left hand) & $28.5 \pm 7.8$ & $24.7 \pm 5.1$ & $26.6 \pm 6.9$ & $29.3 \pm 8.2$ & $24.2 \pm 5.2$ & $26.7 \pm 7.3$ \\
\hline Sit-Ups in $30 \mathrm{~s}$ & $18.4 \pm 3.7$ & $12.9 \pm 5.1$ & $15.6 \pm 5.2$ & $19.2 \pm 4.1$ & $15.4 \pm 4.5$ & $17.3 \pm 4.7$ \\
\hline Bent Arm Hang & $27.5 \pm 22.7$ & $12.5 \pm 12.3$ & $20.0 \pm 19.7$ & $27.8 \pm 21.8$ & $13.6 \pm 13.3$ & $20.7 \pm 19.4$ \\
\hline $10 \times 5 \mathrm{~m}$ Shuttle-Run & $19.3 \pm 1.4$ & $21.4 \pm 1.7$ & $20.4 \pm 1.9$ & $20.5 \pm 2.5$ & $22.3 \pm 2.3$ & $21.4 \pm 2.5$ \\
\hline 20 m endurance Shuttle-Run & $5.3 \pm 1.8$ & $3.7 \pm 1.0$ & $4.5 \pm 1.6$ & $5.4 \pm 1.7$ & $4.0 \pm 1.2$ & $4.7 \pm 1.6$ \\
\hline
\end{tabular}

Table 2 presents descriptives, separately for male and female students from Kosovo and Montenegro. Montenegrin students are taller and heavier, and on average achieve better results in the tests sit-ups in $30 \mathrm{~s}$ and $20 \mathrm{~m}$ endurance shuttle-run. Kosovar students achieve better results in the tests standing broad jump and $10 \times 5 \mathrm{~m}$ shuttle-run. Observing the comparison between boys and girls (not considering the age and country), shows that men are taller and heavier than female and achieve better results in fitness tests: standing broad jump, handgrip test, sit-ups in $30 \mathrm{~s}$, bent arm hang, $10 \times 5 \mathrm{~m}$ shuttle-run and $20 \mathrm{~m}$ endurance shuttle-run, whereas the girls achieve better results only in the test sit-andreach. The observation of male samples shows superior results of Montenegrin participants compared Kosovar in all anthropometric measurements and following fitness tests: plate tapping, sit-and-reach, handgrip test (left hand), sit-ups in $30 \mathrm{~s}$, bent arm hang, $10 \times 5$-m shuttle-run, $20 \mathrm{~m}$ endurance shuttle-run. Moreover, the observation of the results reveals superior results of the Montenegrin sample in all anthropometric measures, and in the case of fitness tests only in the following tests: plate tapping, sit-ups in $30 \mathrm{~s}$, bent arm hang, $10 \times 5$ m shuttle-run, $20 \mathrm{~m}$ endurance shuttle-run. The results presented in Table 2 also show that in the case of both samples of female and males, those from Montenegro are taller and heavier than those from Kosovo. In the case of physical tests, the sample of boys in Montenegro have a higher level of fitness compared to those in Kosovo, and in the case of females the situation is reversed, females in Kosovo recorded better values in several physical tests compared to females in Montenegro.

Table 3 presents descriptive statistics according to the age group and gender. Observing the differences between the results of the anthropometric tests, the largest differences were recorded in body height between the ages of 13-14 $(4.9 \mathrm{~cm})$ and body weight $(5.1 \mathrm{~kg})$. For BMI the biggest difference was registered between 14- and 15-years old with $0.9 \mathrm{~kg} / \mathrm{m}^{2}$. In the fitness tests, the biggest differences were registered between the ages 13 and 14 in the tests: flamingo, plate tapping, sit-and-reach, standing broad jump, handgrip test (right and left hands), sit-ups in $30 \mathrm{~s}$; and for 14-15 years in the tests: $10 \times 5$ m shuttle-run and $20 \mathrm{~m}$ endurance shuttle-run. Observing the differences within gender the largest differences were recorded for male sample for all anthropometric and fitness tests, for all ages. Comparing the performances of the three age categories, the most relevant differences were made at the age of 15, for both samples and the largest differences were found between 13and 14-year-old males, for all anthropometric tests and for most fitness tests. 
Table 3. Descriptive statistics, differenced by age and gender (not considering country).

\begin{tabular}{|c|c|c|c|c|c|c|c|c|c|}
\hline \multirow[b]{3}{*}{ Variables } & \multicolumn{9}{|c|}{ Mean \pm Standard Deviation } \\
\hline & \multicolumn{3}{|c|}{13 Years Old } & \multicolumn{3}{|c|}{14 Years Old } & \multicolumn{3}{|c|}{15 Years Old } \\
\hline & Male & Female & All & Male & Female & All & Male & Female & All \\
\hline Body weight & $159.8 \pm 8.2$ & $159.3 \pm 7.2$ & $159.6 \pm 7.7$ & $166.7 \pm 8.8$ & $162.8 \pm 6.6$ & $164.7 \pm 8.0$ & $171.9 \pm 8.7$ & $163.3 \pm 5.6$ & $167.6 \pm 8.5$ \\
\hline BMI & $19.6 \pm 3.6$ & $19.3 \pm 3.2$ & $19.4 \pm 3.4$ & $20.1 \pm 3.1$ & $20.1 \pm 3.6$ & $20.1 \pm 3.3$ & $21.0 \pm 3.8$ & $21.1 \pm 3.2$ & $21.0 \pm 3.5$ \\
\hline Flamingo & $13.4 \pm 6.2$ & $13.4 \pm 5.6$ & $13.4 \pm 5.9$ & $13.1 \pm 6.0$ & $12.5 \pm 5.8$ & $12.8 \pm 5.8$ & $12.5 \pm 6.3$ & $13.8 \pm 5.6$ & $13.2 \pm 5.9$ \\
\hline Plate Tapping & $10.9 \pm 2.0$ & $10.6 \pm 1.6$ & $10.8 \pm 1.5$ & $10.3 \pm 1.9$ & $10.2 \pm 1.4$ & $10.3 \pm 1.7$ & $9.9 \pm 1.4$ & $10.4 \pm 1.3$ & $10.1 \pm 1.4$ \\
\hline Standing Broad Jump & $151.8 \pm 24.9$ & $137.2 \pm 19.8$ & $144.5 \pm 23.6$ & $164.0 \pm 29.0$ & $138.1 \pm 23.5$ & $151.1 \pm 29.3$ & $172.2 \pm 28.1$ & $136.8 \pm 20.7$ & $154.5 \pm 30.3$ \\
\hline Handgrip Test (right hand) & $26.4 \pm 6.6$ & $24.0 \pm 5.3$ & $25.2 \pm 6.1$ & $31.0 \pm 7.8$ & $26.5 \pm 5.5$ & $28.7 \pm 7.1$ & $36.4 \pm 8.5$ & $27.8 \pm 4.8$ & $32.1 \pm 8.2$ \\
\hline Handgrip Test (left hand) & $24.4 \pm 5.8$ & $22.5 \pm 4.9$ & $23.5 \pm 5.5$ & $28.8 \pm 7.3$ & $24.8 \pm 5.2$ & $26.8 \pm 6.6$ & $33.6 \pm 8.1$ & $26.2 \pm 5.0$ & $29.9 \pm 7.7$ \\
\hline Sit-Ups in $30 \mathrm{~s}$ & $18.2 \pm 4.4$ & $13.9 \pm 4.0$ & $16.1 \pm 4.7$ & $19.2 \pm 3.8$ & $14.2 \pm 4.8$ & $16.7 \pm 5.0$ & $19.2 \pm 3.5$ & $14.5 \pm 6.0$ & $16.8 \pm 5.5$ \\
\hline Bent Arm Hang & $24.6 \pm 21.6$ & $13.5 \pm 12.1$ & $19.1 \pm 18.4$ & $26.9 \pm 22.9$ & $12.8 \pm 12.7$ & $19.8 \pm 19.8$ & $31.6 \pm 21.9$ & $13.0 \pm 13.8$ & $22.3 \pm 20.5$ \\
\hline $10 \times 5$ m Shuttle-Run & $20.1 \pm 2.0$ & $21.7 \pm 1.8$ & $20.9 \pm 2.1$ & $20.0 \pm 2.0$ & $21.8 \pm 2.3$ & $20.8 \pm 2.3$ & $19.7 \pm 2.3$ & $22.3 \pm 2.2$ & $21.0 \pm 2.6$ \\
\hline 20 m endurance Shuttle-Run & $5.3 \pm 1.8$ & $3.8 \pm 1.2$ & $4.6 \pm 1.7$ & $5.2 \pm 1.7$ & $3.9 \pm 1.2$ & $4.6 \pm 1.6$ & $5.7 \pm 1.9$ & $4.0 \pm 1.1$ & $4.8 \pm 1.8$ \\
\hline
\end{tabular}


Table 4. Descriptive statistics within age for Kosovo and Montenegro students (not considering gender).

\begin{tabular}{|c|c|c|c|c|}
\hline \multirow[t]{2}{*}{ Countries } & \multirow[t]{2}{*}{ Variables } & \multicolumn{3}{|c|}{ Mean \pm Standard Deviation } \\
\hline & & 13 Years Old & 14 Years Old & 15 Years Old \\
\hline \multirow{13}{*}{$\begin{array}{l}0 \\
0 \\
0 \\
0 \\
1\end{array}$} & Body height & $49.6 \pm 11.2$ & $53.8 \pm 11.6$ & $56.6 \pm 11.2$ \\
\hline & Body weight & $158.9 \pm 7.6$ & $164.1 \pm 8.1$ & $165.8 \pm 8.0$ \\
\hline & $\mathrm{BMI}$ & $19.5 \pm 3.6$ & $19.9 \pm 3.6$ & $20.5 \pm 3.2$ \\
\hline & Flamingo & $14.1 \pm 6.4$ & $13.5 \pm 6.6$ & $13.2 \pm 5.8$ \\
\hline & Plate Tapping & $10.4 \pm 1.4$ & $10.2 \pm 1.2$ & $10.0 \pm 1.4$ \\
\hline & Sit-and-Reach & $26.5 \pm 7.7$ & $27.9 \pm 8.0$ & $28.6 \pm 9.5$ \\
\hline & Standing Broad Jump & $149.4 \pm 24.5$ & $151.7 \pm 31.4$ & $157.6 \pm 30.9$ \\
\hline & Handgrip Test (right hand) & $26.2 \pm 6.4$ & $28.4 \pm 7.5$ & $32.0 \pm 8.1$ \\
\hline & Handgrip Test (left hand) & $24.2 \pm 5.6$ & $26.1 \pm 6.9$ & $29.5 \pm 7.1$ \\
\hline & Sit-Ups in $30 \mathrm{~s}$ & $15.0 \pm 4.4$ & $15.8 \pm 5.2$ & $16.2 \pm 6.1$ \\
\hline & Bent Arm Hang & $17.8 \pm 17.3$ & $19.8 \pm 21.2$ & $22.5 \pm 20.4$ \\
\hline & $10 \times 5 \mathrm{~m}$ Shuttle-Run & $20.5 \pm 1.7$ & $20.2 \pm 1.9$ & $20.5 \pm 2.1$ \\
\hline & $\begin{array}{l}20 \text { m endurance } \\
\text { Shuttle-Run }\end{array}$ & $4.2 \pm 1.6$ & $4.5 \pm 1.6$ & $5.0 \pm 1.8$ \\
\hline \multirow{13}{*}{ 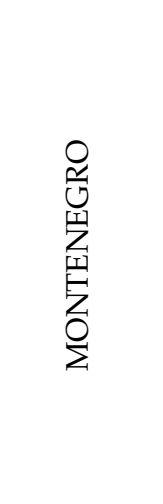 } & Body height & $50.0 \pm 10.5$ & $55.5 \pm 10.4$ & $62.0 \pm 13.4$ \\
\hline & Body weight & $160.3 \pm 7.9$ & $165.5 \pm 7.9$ & $169.4 \pm 8.6$ \\
\hline & BMI & $19.3 \pm 3.3$ & $20.2 \pm 3.0$ & $21.5 \pm 3.7$ \\
\hline & Flamingo & $12.8 \pm 5.2$ & $12.1 \pm 5.0$ & $13.1 \pm 6.1$ \\
\hline & Plate Tapping & $11.2 \pm 2.0$ & $10.3 \pm 2.0$ & $10.2 \pm 1.3$ \\
\hline & Sit-and-Reach & $25.4 \pm 7.2$ & $28.4 \pm 7.9$ & $28.9 \pm 7.6$ \\
\hline & Standing Broad Jump & $139.6 \pm 21.7$ & $150.3 \pm 27.3$ & $151.4 \pm 29.5$ \\
\hline & Handgrip Test (right hand) & $24.2 \pm 5.7$ & $29.1 \pm 6.7$ & $32.2 \pm 8.2$ \\
\hline & Handgrip Test (left hand) & $22.7 \pm 5.2$ & $27.5 \pm 6.3$ & $30.3 \pm 8.2$ \\
\hline & Sit-Ups in $30 \mathrm{~s}$ & $17.1 \pm 4.9$ & $17.6 \pm 4.7$ & $17.4 \pm 4.7$ \\
\hline & Bent Arm Hang & $20.3 \pm 19.3$ & $19.9 \pm 18.3$ & $22.1 \pm 20.7$ \\
\hline & $10 \times 5 \mathrm{~m}$ Shuttle-Run & $21.3 \pm 2.3$ & $21.5 \pm 2.5$ & $21.6 \pm 3.0$ \\
\hline & 20 m endurance shuttle-run & $5.1 \pm 1.7$ & $4.6 \pm 1.6$ & $4.7 \pm 1.8$ \\
\hline
\end{tabular}

Table 5. Multivariate test (Wilks' $\lambda$ ) and explained variance for the model effects.

\begin{tabular}{cccccc}
\hline Effect & $\boldsymbol{\lambda}$ & $\mathbf{F}$ & $\mathbf{d f}$ & $\boldsymbol{p}$ & Partial $\boldsymbol{\eta}^{\mathbf{2}}$ \\
\hline Country & 0.83 & 19.06 & 13 & $<0.000$ & 0.174 \\
Gender & 0.45 & 111.32 & 13 & $<0.000$ & 0.552 \\
Age & 0.75 & 13.85 & 26 & $<0.000$ & 0.133 \\
Country Gender & 0.96 & 3.92 & 13 & $<0.000$ & 0.042 \\
Country Age & 0.93 & 3.34 & 26 & $<0.000$ & 0.036 \\
Gender Age & 0.88 & 5.73 & 26 & $<0.000$ & 0.060 \\
Country & 0.96 & 1.73 & 26 & 0.013 & 0.019 \\
Gender-Age & & & & &
\end{tabular}

Df—-degrees of freedom; $\lambda$ —Wilks lambda; F-Fisher test; $p$ —level of probability; Partial $\eta^{2}$ —partial eta square.

Table 4 represents descriptive statistics, differentiated by age group and country. In the case of anthropometric tests, the sample of Montenegro have a higher level compared to those in Kosovo for all ages. In the case of physical tests, the sample of Montenegro have a higher level of most fitness compared to those in Kosovo. Comparing the performances on the three age categories, the highest values were achieved at the age of 15, for both countries and age groups. The largest differences were found between the 13- and 14-year old students, for most of the fitness tests.

Table 5 represents the results of a multivariate comparisons among variables. All differences between the countries are statistically significant for the whole system of anthropometric and motoric (fitness) variables. Most of the variance (5.2\%) between the groups is explained regarding the gender. The influence between countries is quite large (17.4\% explains the variance), whereas the age explains $13.3 \%$ of variance variability. Also, 
the interactions between the country and the gender, which are statistically significant, but much lower, explain $0,4 \%$ of the variance. The interactions between the country and the age explain $0.4 \%$ of the variance. Gender and age explain $0.6 \%$ of the variance. Country, gender and age explain $0.2 \%$ of variance variability.

Table 6. Univariate ANOVA F-test for the full model and the proportion of explained variance.

\begin{tabular}{ccccccc}
\hline Dependent Variable & Type III Sum of Squares & df & Mean Square & F & $p$ & Partial Eta Squared \\
\hline Body height & $26,215.63$ & 11 & 2383.24 & 18.79 & 0.000 & 0.148 \\
Body weight & $23,867.88$ & 11 & 2169.81 & 38.16 & 0.000 & 0.261 \\
BMI & 632.27 & 11 & 57.48 & 4.97 & 0.000 & 0.044 \\
Flamingo & 687.31 & 11 & 62.48 & 1.80 & 0.049 & 0.016 \\
Plate Tapping & 221.95 & 11 & 20.18 & 7.93 & 0.000 & 0.068 \\
Sit-and-Reach & 9840.14 & 11 & 894.56 & 15.49 & 0.000 & 0.125 \\
Standing Broad Jump & $260,400.09$ & 11 & $23,672.74$ & 40.50 & 0.000 & 0.273 \\
Handgrip Test (right hand) & $19,983.19$ & 11 & 1816.65 & 42.38 & 0.000 & 0.282 \\
Handgrip Test (left hand) & $16,432.62$ & 11 & 1493.88 & 39.67 & 0.000 & 0.269 \\
Sit-Ups in 30 s & 7912.62 & 11 & 719.33 & 37.28 & 0.000 & 0.257 \\
Bent Arm Hang & $70,809.77$ & 11 & 6437.25 & 19.59 & 0.000 & 0.154 \\
10 $\times$ 5 m Shuttle-Run & 1652.02 & 11 & 150.18 & 36.39 & 0.000 & 0.252 \\
20 & 808.88 & 11 & 73.53 & 33.42 & 0.000 & 0.236 \\
\hline
\end{tabular}

Df—degrees of freedom; F-Fisher test, $p$-level of probability.

Table 7. Univariate F-test significance and the proportion of explained variance for the model effects.

\begin{tabular}{|c|c|c|c|c|c|c|c|c|c|c|c|c|c|c|}
\hline \multirow[t]{2}{*}{ Variables } & \multicolumn{2}{|c|}{ Country } & \multicolumn{2}{|c|}{ Gender } & \multicolumn{2}{|c|}{ Age } & \multicolumn{2}{|c|}{$\begin{array}{c}\text { Country }{ }^{*} \\
\text { Gender }\end{array}$} & \multicolumn{2}{|c|}{$\begin{array}{c}\text { Country } \\
\text { Age }\end{array}$} & \multicolumn{2}{|c|}{$\begin{array}{c}\text { Gender * } \\
\text { Age }\end{array}$} & \multicolumn{2}{|c|}{$\begin{array}{c}\text { Country * } \\
\text { Gender* Age }\end{array}$} \\
\hline & $p$ & $\eta^{2}$ & $p$ & $\eta^{2}$ & $p$ & $\eta^{2}$ & $p$ & $\eta^{2}$ & $p$ & $\eta^{2}$ & $p$ & $\eta^{2}$ & $p$ & $\eta^{2}$ \\
\hline Body height & 0.00 & 0.01 & 0.00 & 0.02 & 0.00 & 0.11 & 0.47 & 0.00 & 0.01 & 0.01 & 0.01 & 0.01 & 0.19 & 0.00 \\
\hline Body weight & 0.00 & 0.02 & 0.00 & 0.08 & 0.00 & 0.16 & 0.78 & 0.00 & 0.07 & 0.00 & 0.00 & 0.05 & 0.14 & 0.00 \\
\hline BMI & 0.07 & 0.00 & 0.75 & 0.00 & 0.00 & 0.04 & 0.45 & 0.00 & 0.05 & 0.01 & 0.64 & 0.00 & 0.60 & 0.00 \\
\hline Flamingo & 0.01 & 0.01 & 0.50 & 0.00 & 0.31 & 0.00 & 0.41 & 0.00 & 0.21 & 0.00 & 0.09 & 0.00 & 0.66 & 0.00 \\
\hline Plate Tapping & 0.00 & 0.01 & 0.94 & 0.00 & 0.00 & 0.03 & 0.01 & 0.01 & 0.02 & 0.01 & 0.00 & 0.02 & 0.09 & 0.00 \\
\hline Sit-and-Reach & 0.83 & 0.00 & 0.00 & 0.10 & 0.00 & 0.02 & 0.04 & 0.00 & 0.27 & 0.00 & 0.52 & 0.00 & 0.75 & 0.00 \\
\hline Standing Broad Jump & 0.00 & 0.01 & 0.00 & 0.22 & 0.00 & 0.03 & 0.00 & 0.01 & 0.05 & 0.01 & 0.00 & 0.03 & 0.00 & 0.01 \\
\hline Handgrip Test (right hand) & 0.39 & 0.00 & 0.00 & 0.14 & 0.00 & 0.16 & 0.42 & 0.00 & 0.01 & 0.01 & 0.00 & 0.04 & 0.47 & 0.00 \\
\hline Handgrip Test (left hand) & 0.64 & 0.00 & 0.00 & 0.12 & 0.00 & 0.16 & 0.07 & 0.00 & 0.00 & 0.01 & 0.00 & 0.03 & 0.30 & 0.00 \\
\hline Sit-Ups in $30 \mathrm{~s}$ & 0.00 & 0.04 & 0.00 & 0.22 & 0.03 & 0.01 & 0.00 & 0.01 & 0.43 & 0.00 & 0.52 & 0.00 & 0.10 & 0.00 \\
\hline Bent Arm Hang & 0.50 & 0.00 & 0.00 & 0.14 & 0.03 & 0.01 & 0.74 & 0.00 & 0.46 & 0.00 & 0.01 & 0.01 & 0.27 & 0.00 \\
\hline $10 \times 5 \mathrm{~m}$ Shuttle-Run & 0.00 & 0.06 & 0.00 & 0.19 & 0.44 & 0.00 & 0.11 & 0.00 & 0.27 & 0.00 & 0.00 & 0.01 & 0.00 & 0.01 \\
\hline $\begin{array}{l}20 \text { m endurance } \\
\text { Shuttle-Run }\end{array}$ & 0.02 & 0.00 & 0.00 & 0.21 & 0.02 & 0.01 & 0.65 & 0.00 & 0.00 & 0.03 & 0.04 & 0.01 & 0.09 & 0.00 \\
\hline
\end{tabular}

${ }^{*}$ Level of probability $p \leq 0.05$.

Table 6 represents the results of a univariate comparisons among variables. Univariate test for main factors and mutual interaction indicated the statistically significant influence on all independent variables. These variables have greatest influence regarding the gender. When both Kosovar and Montenegrin students are compared as a whole, not considering the age and gender, statistically significant differences between the countries can be found.

Table 7 represents univariate interactions between country and gender. Interactions were found to be are small and in the range of $0.1 \%$ explain the variance of variable sit-ups in $30 \mathrm{~s}$ and the variable plate tapping. Univariate interactions between country and age are also small and in the range of $0.3 \%$ to explain the variance of variable $20 \mathrm{~m}$ endurance shuttle-run up to $0.1 \%$ to explain the variance of variables: standing broad jump, handgrip test, plate tapping, body weight, and BMI. Univariate interactions between gender and age are in the range of $0.5 \%$ to explain the variance of variable body height, $0.3 \%$ to explain the variance of variables standing broad jump and handgrip test (left hand), up to $0.1 \%$ to 
explain the variance of variables bent arm hang, $10 \times 5 \mathrm{~m}$ shuttle-run and bent arm hang. Univariate interactions between country, gender, and age are very small and in the range of $0.1 \%$ to explain the variance of the variables standing broad jump and $10 \times 5 \mathrm{~m}$ shuttle-run As shown in Table 7 , statistically significant differences $(p<0.5)$ related to gender country ages were achieved in all variables, except for the variable flamingo and sit-and-reach.

\section{Discussion}

The results from this research show that the adolescent sample from Montenegro is statistically significant different from the adolescent sample from Kosovo in a certain number of researched variables. Statistically significant differences were not identified in the variables BMI, plate tapping, flamingo, sit-and-reach, handgrip test and bent arm hang. Therefore, we can only partly confirm our first hypothesis. Montenegrin students are heavier and taller and achieve better results in the tests sit-ups in $30 \mathrm{~s}$ and $20 \mathrm{~m}$ endurance shuttle-run. Kosovar students achieve better results in the tests standing broad jump and 10 $\times 5 \mathrm{~m}$ shuttle-run. Moreover, our second hypothesis can be confirmed, while we assessed higher anthropometric values and better physical fitness results at older (15 compared to 14 and 13 years old) and male students.

As mentioned above, there is a possibility that the genetics, geographical environment and different eating habits [11,43-47] play a key role for the differences in morphological characteristics and motoric (fitness) abilities. Although previous researches did not provide a final answer to these questions, a greater number of studies show that the social and economic conditions in which the individual lives and their ecosystem are related to the level of motoric (fitness) abilities, as well as some morphological characteristics [48]. According to research [49], a higher socioeconomic status is in negative ratio with the BMI. In other terms, in more developed countries with a better socioeconomic status, there is a lower prevalence of obesity. Determined differences in motoric abilities among adolescents from Kosovo and Montenegro could be due to the differences in curricula and programs in physical education and different settings for teaching. According to European Commission, there are differences in curricula and programs in European countries. About a third of educational systems in Europe have two levels of teaching for physical education: obligatory and optional programs [42].

Furthermore, the results from the research point out that the males have higher body weight and body height, and achieve better results in the tests: standing broad jump, handgrip test, sit-ups in $30 \mathrm{~s}$, bent arm hang, $10 \times 5 \mathrm{~m}$ shuttle-run, and 20-m endurance shuttle-run, whereas the females achieve better results only in the test sitand-reach. During the whole period of growth between 13th and 15th year, the females are lower and have smaller body weight in comparison to the males [50,51]. Gender disparities in the period of adolescence in combination with the effects of endocrine adaptation (influence of gonadal steroid hormones and the growth hormone) typical for sexual maturing, morphological differences, primarily in body composition (the content of minerals in bones and muscle mass is increased among males, whereas the accumulation of fat around the hips is decreased), functional differences, and physical activity are the main factors for motoric differences in the age between 13 and 15 between males and females. In this period, a stabilization of morphological and functional features arises. On the other hand, in this period, males are mainly more included in organized forms of practice and spontaneous physical activities, unlike females, which contributes to an improvement, among other things, of strength, that contributes to an improvement of other motoric tasks. In this period, there are sharp differences in body composition (males have a higher percentage of muscular mass, whereas the females have a higher percentage of fat tissue), as well as differences in hemoglobin concentration. Body mass (especially passive mass) is not an obstacle for males, as is the case with female population. The effects of endocrine adaptation that is typical for sexual maturing, increase the level of testosterone and growing hormone (GH). The level of testosterone [52] is increased by four times in the early phases of puberty, up to 20 times in the middle and the end of puberty among 
males. Testosterone stimulates anabolic processes (protein synthesis) in skeletal muscles and is probably responsible for the sharp differences in strength among this age category. The higher percentage of muscle mass, hemoglobin concentration, higher physical activity in adolescence phase are probably the main factors that cause the differences in aerobic capacity between males and females. Similar results noted that during adolescence there are differences that arise in motoric abilities and those are mostly expressed at the age of 13. Moreover, some studies stated that weaker motoric among females could not be prescribed only to morphological specifics, but also to the lower level of physical activity, and especially to the lower engagement in sport and recreational activities [53-58]. Studies underlined that, with increasing age, motoric abilities are improved, and the females reach the top in motoric abilities at age 14-15 [59-61]. The researchers showed that more than $80 \%$ of the females and $70 \%$ of the males at age 11 do not have recommended physical activity, whereas $85 \%$ of the females and $69 \%$ of the males do not have recommended physical activity at age 13, which indicates that the prevalence of insufficient physical activity is higher among females than males [62-64]. A longitudinal study [65] which was realized in three-year period shows that females spend more hours in sitting activities (reading, watching TV, working on a computer) in comparison to the males who usually spend their spare time in playing sports or various types of games. The better results that females achieve in the test sit-and-reach regardless age and country are due to the differences in growth and development level of connective, muscle, and bone tissue, as well as the difference in anatomy of the hip joint and pelvis between males and females [66-70].

Considering the examined variable regarding the age, it was noted that regardless the gender and country (except in the variable flamingo), there are statistically significant differences in all variables. Body height and weight are in accordance with the typical dynamics of growth and development, although the increasing of BMI (body mass index) is a concerning fact that might indicate that obesity in adolescents increases when maturing.

The strengths of the study were, as follows: investigating two neighboring countries, the large number of tests investigating anthropometric and physical fitness levels and comparative evaluation by gender, age, country. In the same breath, there are some limitations regarding to our study that need to be addressed. Comparisons of two countries in isolation can represent a limitation, i.e., lack objectivity. Moreover, gender comparisons based only on chronological age could have biased our data. According to the gained results, future studies should focus on examining the genetic, living environment, geographic region, cultural specifics, socioeconomic status, different eating habits, as well as the impact of different physical education curricula on motor abilities. Moreover, providing an interquartile range of the particular tests would provide more information for sports teachers when preparing the content of physical education programs.

\section{Conclusions}

On the basis of the achieved results, it could be concluded that the Montenegrin students are taller and heavier and achieve better results when tested for sit-ups in 30 $\mathrm{s}$ and $20 \mathrm{~m}$ endurance shuttle-run. The students of Kosovo achieve better results in the tests standing broad jump and shuttle-run $10 \times 5 \mathrm{~m}$. The males are significantly taller and heavier than females and achieve better results in fitness tests: standing broad jump, handgrip test, sit-ups in $30 \mathrm{~s}$, bent arm hang, $10 \times 5 \mathrm{~m}$ shuttle-run, and 20-m endurance shuttle-run, whereas the females achieve better results only in the test sit-andreach. Considering the examined variables regarding the age, it was noted that there are statistically significant differences in all variables, regardless of the gender and country (except for the variable flamingo). In order to facilitate a comparison between various countries, as well as easier following of the trends, a continuous observation of fitness level and physical activity is needed, at both global and national level, as well as an assimilation of a methodology for the assessment of physical activity and fitness level. High prevalence of physical inactivity among children and adolescents requires preparation of strategies of education for all kind of ages for change of the habits for health and physical activity. The 
study is of importance to physical education teachers and curriculum authors to optimize students' proactive behavior based on the identified anthropometric and physical fitness weaknesses from the results of our study. While the assessed differences between counties could be attributed to the programs of physical education, as well as the number, proximity, and access to sports objects, examples of good practice could serve as a cornerstone for the improvement of physical education program contents and, consequently, proactive behavior of the students.

Author Contributions: Conceptualization, B.M., F.M. and D.B.; methodology, B.M., F.M. and D.B.; software, B.M., F.M.; validation, B.M., F.M. and D.B.; formal analysis, B.M., F.M. and D.B.; investigation, B.M., F.M.; resources, B.M., F.M.; data curation, B.M., F.M.; writing-original draft preparation, B.M., F.M. and D.B.; writing-review and editing, B.M., F.M. and D.B.; visualization, B.M., F.M. and D.B.; supervision, B.M., F.M. and D.B.; All authors have read and agreed to the published version of the manuscript.

Funding: This research received no external funding.

Institutional Review Board Statement: The protocol was approved by the Ethics Committee of Faculty of Physical Education and Sport, Pristina, no. 16/02.2019.

Informed Consent Statement: Informed consent was obtained from all subjects involved in the study.

Conflicts of Interest: The authors declare no conflict of interest.

\section{References}

1. Foster, H.M.E.; Ho, F.K.; Sattar, N.; P Wels, P.; Pell, J.P.; Gill, J.M.R.; Gray, S.R.; Celis-Morales, C.A. Understanding How Much TV is Too Much: A Nonlinear Analysis of the Association Between Television Viewing Time and Adverse Health Outcomes. Mayo Clin. Proc. 2020, 95, 2429-2441. [CrossRef] [PubMed]

2. Silva, P.; Sousa, M.; Aires, L.; Seabra, A.; Ribeiro, J.; Welk, G.; Mota, J. Physical activity patterns in Portuguese adolescents: The contribution of extracurricular sports. Eur. Phys. Educ. Rev. 2010, 16, 171-181. [CrossRef]

3. Park, J.H.; Moon, J.H.; Kim, H.J.; Kong, M.H.; Oh, Y.H. Sedentary Lifestyle: Overview of Updated Evidence of Potential Health Risks. Korean J. Fam. Med. 2020, 41, 365-373. [CrossRef] [PubMed]

4. Cabanas-Sánchez, V.; Martínez-Gómez, D.; Izquierdo-Gómez, R.; Segura-Jiménez, V.; Castro-Piñero, J.; Veiga, O.L. Association between Clustering of Lifestyle Behaviors and Health-Related Physical Fitness in Youth: The UP\&DOWN Study. J. Pediatr. 2018, 199, 41-48. [CrossRef] [PubMed]

5. Armstrong, N.; Welsman, J.R. The physical activity patterns of European youth with reference to methods of assessment. Sports Med. 2006, 36, 1067-1086. [CrossRef]

6. Ferreira, I.; van der Horst, K.; Wendel-Vos, W.; Kremers, S.; van Lenthe, F.J.; Brug, J. Environmental correlates of physical activity in youth-A review and update. Obes. Rev. 2006, 8, 129-154. [CrossRef]

7. Barnett, T.A.; Kelly, A.S.; Young, D.R.; Perry, C.K.; Pratt, C.A.; Edwards, N.M.; Rao, G.; Vos, M.B. American Heart Association Obesity Committee of the Council on Lifestyle and Cardiometabolic Health; Council on Cardiovascular Disease in the Young; and Stroke Council. Sedentary Behaviors in Today's Youth: Approaches to the Prevention and Management of Childhood Obesity: A Scientific Statement from the American Heart Association. Circulation 2018, 138, e142-e159. [CrossRef]

8. Cureau, F.V.; Sparrenberger, K.; Bloch, K.V.; Ekelund, U.; Schaan, B.D. Associations of multiple unhealthy lifestyle behaviors with overweight/obesity and abdominal obesity among Brazilian adolescents: A country-wide survey. Nutr. Metab. Cardiovasc. Dis. 2018, 28, 765-774. [CrossRef]

9. Olds, T.S.; Ridley, K.; Tomkinson, G.R. Declines in aerobic fitness: Are they only due to increasing fatness? Med. Sport Sci. 2007, $50,226-240$.

10. López-Gil, J.F.; Brazo-Sayavera, J.; García-Hermoso, A.; Camargo, E.M.; Yuste Lucas, J.L. Clustering Patterns of Physical Fitness, Physical Activity, Sedentary, and Dietary Behavior among School Children. Child Obes. 2020, 16, 564-570. [CrossRef] [PubMed]

11. Strauss, R.; Pollack, H. Epidemic in childhood overweight, 1986-1998. J. Am. Med Assoc. 2001, 286, 2845-2848. [CrossRef] [PubMed]

12. Lobstein, T.; Frelut, M.L. Prevalence of overweight among young people in Europe. Obes. Rev. 2003, 4, 1195-2000. [CrossRef] [PubMed]

13. Wedderkopp, N.; Froberg, K.; Hansen, H.; Andersen, L. Secular trend in physical fitness and obesity in Danish 9-years old females and males. An Odense School Child Study and Danish substudy of the European Youth Heart Study. Scand. J. Med. Sci. Sport 2004, 14, 150-155. [CrossRef] [PubMed]

14. Malina, R.M. Physical fitness of children and adolescents in the United States: Status and secular change. Med. Sport Sci. 2007, 50, 67-90. 
15. Frömel, K.; Groffik, D.; Mitáš, J.; Madarasová Gecková, A.; Csányi, T. Physical Activity Recommendations for Segments of School Days in Adolescents: Support for Health Behavior in Secondary Schools. Front Public Health 2020, 30, 527442. [CrossRef]

16. Harrington, D.M.; Davies, M.; Bodicoat, D.; Charles, J.M.; Chudasama, Y.V.; Gorely, T.; Khunti, K.; Rowlands, A.V.; Sherar, L.B.; Tudor-Edwards, R.; et al. A school-based intervention ('Females Active') to increase physical activity levels among 11- to 14-year-old females: Cluster RCT. Public Health Res. 2019, 7, 1-162. [CrossRef] [PubMed]

17. Westerståhl, M.; Barnekow-Bergkvist, M.; Jansson, E. Low physical activity among adolescents in practical education. Scand. J. Med. Sci. Sports 2005, 15, 287-297. [CrossRef]

18. Tomkinson, G.R.; Olds, T.S. Secular changes in pediatric aerobic fitness test performance: The global picture. Med. Sport Sci. 2007, $50,46-66$.

19. Mok, M.M.C.; Chin, M.K.; Korcz, A.; Popeska, B.; Edginton, C.R.; Uzunoz, F.S.; Podnar, H.; Coetzee, D.; Georgescu, L.; Emeljanovas, A.; et al. Brain Breaks ${ }^{\circledR}$ Physical Activity Solutions in the Classroom and on Attitudes toward Physical Activity: A Randomized Controlled Trial among Primary Students from Eight Countries. Int. J. Environ. Res. Public Health 2020, 4, 1666. [CrossRef]

20. Massari, G.A.; Miron, F.M. A comparative study on teaching practices in early childhood education. In Proceedings of the 5th International Conference on Adult Education (CIEA), Iasi, Romania, 25-28 April 2018; pp. 543-551.

21. Mirwald, R.L.; Baxter-Jones, A.D.; Bailey, D.A.; Beunen, G.P. An assessment of maturity from anthropometric measurements. Med. Sci. Sports Exerc. 2002, 34, 689-694. [CrossRef]

22. Prainsack, B.; Buyx, A. Solidarity in contemporary bioethics-towards a new approach. Bioethics 2012, 26, 343-350. [CrossRef]

23. Jakubec, L.; Frömel, K.; Chmelík, F.; Groffik, D. Physical Activity in 15-17-Year-Old Adolescents as Compensation for Sedentary Behavior in School. Int. J. Environ. Res. Public Health. 2020, 17, 3281. [CrossRef]

24. Neljak, B.; Novak, D.; Sporiš, G.; Višković, S.; Markuš, D. Metodologija Vrednovanja Kinantropoloških Obilježja Učenika u Tjelesnoj i Zdravstvenoj Kulturi. Crofit Norme; Kineziološki fakultet: Zagreb, Croatia, 2012.

25. Aarts, M.J.; Mathijssen, J.J.; van Oers, J.A.; Schuit, A.J. Associations between environmental characteristics and active commuting to school among children: A cross-sectional study. Int. J. Behav. Med. 2013, 20, 538-555. [CrossRef]

26. Malina, R.M.; Peña Reyes, M.E.; Little, B.B. Secular change in the growth status of urban and rural schoolchildren aged 6-13 years in Oaxaca, southern Mexico. Ann. Hum. Biol. 2008, 35, 475-489. [CrossRef]

27. Sánchez-Oliva, D.; Grao-Cruces, A.; Carbonell-Baeza, A.; Cabanas-Sánchez, V.; Veiga, O.L.; Castro-Piñero, J. Lifestyle Clusters in School-Aged Youth and Longitudinal Associations with Fatness: The UP\&DOWN Study. J. Pediatr. 2018, 203, 317-324.e1. [CrossRef]

28. Hebbelinck, M.; Clarys, P.; de Malsche, A. Growth, development, and physical fitness of Flemish vegetarian children, adolescents, and young adults. Am. J. Clin. Nutr. 1999, 70, 79-85. [CrossRef] [PubMed]

29. Jurak, G. Sporting lifestyle vs. 'cigarettes; coffee' lifestyle of Slovenian high school students. Anthr. Noteb. 2006, $12,79-95$.

30. Freitas, D.L.; Maia, J.; Beunen, G.P.; Ramos, C.; Freitas, D.; Maia, J.A.; Beunen, G.P.; Claessens, A.L.; Gouveia, E.R.; Marques, A.T.; et al. Socioeconomic status, growth, physical activity and fitness: The Madeira Growth Study. Ann Hum Biol. 2007, 34, 107-122. [CrossRef] [PubMed]

31. Kolle, E.; Solberg, R.B.; Säfvenbom, R.; Dyrstad, S.; Berntsen, S.; Resaland, G.; Ekelund, U.; Anderssen, S.; Steene-Johannessen, J.; Grydeland, M. The effect of a school-based intervention on physical activity, cardiorespiratory fitness and muscle strength: The School in Motion cluster randomized trial. Int. J. Behav. Nutr. Phys. Act. 2020, 17, 154. [CrossRef] [PubMed]

32. Raicea, V.; Kovacs, J.; Moraru, L.; Suciu, H. Coronary Sinus Lactate as Marker of Myocardial Ischemia in Cardiac Surgery: Correlation with Morbidity and Mortality after Cardiac Surgery. Rev. Romana Med. Lab. 2015, 23, 189-197. [CrossRef]

33. Almeida, M.B.; Leandro, C.G.; Queiroz, D.D.R.; José-da-Silva, M.; Pessôa Dos Prazeres, T.M.; Pereira, G.M.; das-Neves, G.S.; Carneiro, R.C.; Figueredo-Alves, A.D.; Nakamura, F.Y.; et al. Plyometric training increases gross motor coordination and associated components of physical fitness in children. Eur. J. Sport Sci. 2020, 10, 1-10. [CrossRef] [PubMed]

34. Caspersen, C.J.; Powell, K.E.; Christenson, G.M. Physical activity, exercise, and physical fitness: Definitions and distinctions for health-related research. Public Health Rep. 1985, 100, 126-131. [PubMed]

35. Fühner, T.; Kliegl, R.; Arntz, F.; Kriemler, S.; Granacher, U. An Update on Secular Trends in Physical Fitness of Children and Adolescents from 1972 to 2015: A Systematic Review. Sports Med. 2021, 51, 303-320. [CrossRef] [PubMed]

36. Jankauskiene, R.; Baceviciene, M.; Pajaujiene, S.; Badau, D. Are Adolescent Body Image Concerns Associated with HealthCompromising Physical Activity Behaviours? Int. J. Environ. Res. Public Health 2019, 16, 1225. [CrossRef] [PubMed]

37. Charlton, R.; Gravenor, M.B.; Rees, A.; Knox, G.; Hill, R.; Rahman, M.A.; Jones, K.; Christian, D.; Baker, J.S.; Stratton, G.; et al. Factors associated with low fitness in adolescents-A mixed methods study. BMC Public Health 2014, 14, 1-10. [CrossRef]

38. Dasso, N.A. How is exercise different from physical activity? A concept analysis. Nurs. Forum 2019, 54, 45-52. [CrossRef]

39. Armstrong, N.; Welsman, J.O. Traditional and New Perspectives on Youth Cardiorespiratory Fitness. Med. Sci. Sports Exerc. 2020, 52, 2563-2573. [CrossRef]

40. Sousa, A.W.; Cabral, A.L.B.; Silva, R.A.; Fonseca, A.J.; Grindler, J.; Martins, M.A.; Carvalho, C.R.F. Physical fitness and quality of life in adolescents with asthma and fixed airflow obstruction. Pediatr. Pulmonol. 2021, 56, 65-73. [CrossRef]

41. Tsigilis, N.; Douda, H.; Tokmakidis, S.P. Test-retest reliability of the Eurofit test battery administered to university students. Percept. Mot. Skills. 2002, 95, 1295-1300. [CrossRef] 
42. European Commission/EACEA/Eurydice. Physical Education and Sport at School in Europe Eurydice Report; Publications Office of the European Union: Luxembourg, 2013.

43. Bruijns, B.A.; Johnson, A.M.; Tucker, P. Content development for a physical activity and sedentary behaviour e-learning module for early childhood education students: A Delphi study. BMC Public Health 2020, 20, 1600. [CrossRef]

44. Prskalo, I.; Kraljević, Ž.; Kovačić, M. Mjesto stanovanja prediktor spolnog dimorfizma nekih motoričkih sposobnosti u primarnoj edukaciji. In Proceedings of the 6th FIEP European Congress, Poreč, Croatia, 18-21 June 2011; Prskalo, I., Novak, D., Eds.; pp. 394-399.

45. Richards, K.; Andrew, R. Role Socialization Theory: The Sociopolitical Realities of Teaching Physical Education. Eur. Phys. Educ. Rev. 2015, 21, 379-393. [CrossRef]

46. Jimenez Pavon, D.; Ortega, F.B.; Ruiz, J.; Chillon, P.; Castillo, R.; Artero, E.G.; Martinez Gomez, G.; Rey Lopez, J.P.; Gracia, A.L.; Noriega, M.J.; et al. Influence of socioeconomic factors on fitness and fatness in Spanish adolescents: The AVENA study. Int. J. Pediatric Obes. 2010, 5, 467-473. [CrossRef]

47. Carayanni, V.; Vlachopadopoulou, E.; Koutsouki, D.; Bogdanis, G.C.; Psaltopoulou, T.; Manios, Y.; Karachaliou, F.; Hatzakis, A.; Michalacos, S. Effects of Body Mass Index (BMI), demographic and socioeconomic factors on organized physical activity (OPA) participation in children aged 6-15 years: A cross-sectional study comparing primary and secondary school children in Greece. BMC Pediatr. 2020, 20, 491. [CrossRef] [PubMed]

48. Jimenez Pavon, J.; Ortega, F.B.; Ruiz, J.R.; Espańa Romero, V.; García Artero, E.; Moliner Urdiales, D.; Gómez Martínez, S.; Vicente Rodríguez, G.; Manios, Y.; Béghin, L.; et al. Socioeconomic status influences physical fit- ness in European adolescents independently of body fat and physical activity: The HELENA Study. Nutr. Hosp. 2010, 25, 311-316. [PubMed]

49. Puciato, D.; Rozpara, M. Demographic and Socioeconomic Determinants of Body Mass Index in People of Working Age. Int. J. Environ. Res. Public Health 2020, 17, 8168. [CrossRef]

50. Urchaga, J.D.; Guevara, R.M.; Cabaco, A.S.; Moral-García, J.E. Life Satisfaction, Physical Activity and Quality of Life Associated with the Health of School-Age Adolescents. Sustainability 2020, 12, 9486. [CrossRef]

51. Mišigoj-Duraković, M. Kinantropologija—Biološki Aspekti Tjelesnog Vježbanja; Kineziološki Fakultet Sveučilišta u Zagrebu: Zagreb, Croatia, 2008.

52. Mereuta, C.; Talaghir, L.G.; Manolache, G.; Iconomescu, T. The influence of somatic parameters on the energetic parameters provided by the MGM test. Ann. Univ. Dunarea Jos Galati Fascicle XV Phys. Educ. Sport Manag. 2011, 1, $194-198$.

53. Mraković, M.; Findak, V.; Metikoš, D.; Neljak, B. Developmental characteristics of motor and functional abilities in primary and secondary school pupils. Kineziologija 1996, 28, 62-70.

54. Strel, J.; Kovač, M.; Rogelj, A.; Leskošek, B.; Jurak, G.; Starc, G.; Majerič, M.; Kolenc, M. Ovrednotenje Spremljave Gibalnega in Telesnega Razvoja Otrok in Mladine v Šolskem Letu 2001-2002 in Primerjava Nekaterih Parametrov Športnovzgojnega Kartona s Šolskim Letom 2000-2001 ter z Obdobjem 1990-2000; Zavod za Šport Slovenije: Ljubljana, Slovenia, 2003.

55. Omodior, O.; Ramos, W.D. Social Determinants of Health-Related Quality of Life: A Recreation Setting Analysis. Health Promot Pract. 2020, 21, 952-961. [CrossRef]

56. Badau, A. Study of somatic, motor and functional effects of practicing initiation programs in water gymnastics and swimming by students of physical education and sports. Phys. Educ. Stud. 2017, 21, 158-164. [CrossRef]

57. Badau, A.; Rachita, A.; Sasu, C.R.; Clipa, A. Motivations and the Level of Practicing Physical Activities by Physio-Kinetotherapy Students. Educ. Sci. 2018, 8, 97. [CrossRef]

58. Flanagan, E.W.; Perry, A.C. Perception of Physical Fitness and Exercise Self-Efficacy and Its Contribution to the Relationship between Body Dissatisfaction and Physical Fitness in Female Minority Children. Int. J. Environ. Res. Public Health. 2018, 15, 1187. [CrossRef] [PubMed]

59. Tudor, V.; Mujea, A.M.; Vãrzaru, C.G. Experimental study for improving the speed using the differentiated instruction in 5th grade in the physical education classes. Marathon 2014, 6, 96-100.

60. Iconomescu, T.M.; Talaghir, L.G.; Mereuţă, C.; Manolache, G.M. Application of differentiation in the treatment of lesson of physical education in secondary level meant to build motor skills and abilities for specific game and sports. Ann. Univ. Dunarea Jos Galati Fascicle XV Phys. Educ. Sport Manag. 2011, 1, 48-52.

61. Palmer, H.A.; Newell, K.M.; Mulloy, F.; Gordon, D.; Smith, L.; Williams, G.K.R. Movement form of the overarm throw for children at 6, 10 and 14 years of age. Eur. J. Sport Sci. 2020, 4, 1-9. [CrossRef] [PubMed]

62. Andersen, E.; Øvreås, S.; Jørgensen, K.A.; Borch-Jenssen, J.; Moser, T. Children's physical activity level and sedentary behaviour in Norwegian early childhood education and care: Effects of a staff-led cluster-randomised controlled trial. BMC Public Health 2020, 20, 1651. [CrossRef] [PubMed]

63. Manolache, G. The Stretching Programme-Key Factor for Prevent Injuries of "U” 16 Soccer Players. Ann. Univ. Dunarea Jos Galati Fascicle XV Phys. Educ. Sport Manag. 2018, 1, 28-31. [CrossRef]

64. Badau, D.; Badau, A. Identifying the Incidence of Exercise Dependence Attitudes, Levels of Body Perception, and Preferences for Use of Fitness Technology Monitoring. Int. J. Environ. Res. Public Health 2018, 15, 2614. [CrossRef] [PubMed]

65. McHale, S.M.; Crouter, A.C.; Tucker, C.J. Free-time activities in middle childhood: Links with adjustment in early adolescence. Child Dev. 2001, 72, 1764-1778. [CrossRef]

66. De Castro Pinto, J.B.; Cruz, J.P.S.; de Pinho, T.M.P.; de Dias Marques, A.S.P. Health-related physical fitness of children and adolescents in Portugal. Child. Youth Serv. Rev. 2020, 117, 105279. [CrossRef] 
67. Baquet, G.; Twisk, J.W.; Kemper, H.C.; Van Praagh, E.; Berthoin, S. Longitudinal follow-up of fitness during childhood: Interaction with physical activity. Am. J. Hum. Biol. 2006, 18, 51-58. [CrossRef]

68. Cole, T.J.; Bellizzi, M.C.; Flegal, K.M.; Dietz, W.H. Establishing a standard definition for child overweight and obesity worldwide: International survey. BMJ 2000, 320, 1240-1243. [CrossRef] [PubMed]

69. Kulinna, P.H.; Martin, J.; Lai, Q.; Kliber, A. Students physical activity patterns: Grade, gender, and activity influences. J. Teach. Phys. Educ. 2003, 22, 298-310. [CrossRef]

70. Koutedakis, Y.; Bouziotas, C. National physical education curriculum: Motor and cardiovascular health related fitness in Greek adolescents. Br. J. Sports Med. 2003, 37, 311-314. [CrossRef] [PubMed] 